\title{
CORRELATION BETWEEN FRACTURES AND ABUSE IN CHILDREN: A RETROSPECTIVE ANALYSIS
}

\author{
RELAÇÃO ENTRE FRATURAS E SUSPEITA DE MAUS TRATOS \\ EM CRIANÇAS: UMA ANÁLISE RETROSPECTIVA
}

\author{
Vitor Luis Pereira ${ }^{1}$ (i), Bernardo lopes Crisostomo ${ }^{1}$ (i), Givlia Carvalho Silva ${ }^{1}$ (i), Eiffel Tsuyoshi Dobashi ${ }^{1}$ (i) \\ 1. Universidade Federal de São Paulo, Paulista School of Medicine, Department of Orthopedics and Traumatology, São Paulo, SP, Brazil.
}

\section{ABSTRACT}

Objective: The aim of this work is to provide evidence for the relationship between suspicion and diagnosis of cases of child abuse and fractures, since, in national literature, studies are still scarce on the subject. Methods: Retrospective study involving electronic medical records of a public reference hospital, in a city of the state of São Paulo, in a 8-year period (2010 to 2018). Cases involving children up to 12 years of age were selected when notified as abuse and presenting fractures; data were statistically analyzed. Results: Among 83 cases of abuse, 19 patients (20.5\%) had 23 different fractures. The victims were mainly boys (68.42\%) with a mean age of 5 years old, who suffered physical aggression (79\%). The majority had no identified aggressor (52\%) and $21 \%$ were related to the mother. The fracture patterns found involved, mostly, skull fractures (43.48\%) and diaphysary fractures (34.78\%). Seven patients (30.43\%) had other associated lesions and four patients died (21\%). Conclusion: Despite the number of cases, it was possible to identify relevant characteristics and patterns. These data indicate that the diagnosis is underestimated and show small epidemiological differences compared with international literature. Level of Evidence II, Retrospective study.

Keywords: Child abuse. Aggression. Bone Fractures. Child.

\section{RESUMO}

Objetivo: O objetivo deste trabalho é fornecer evidências para a relação entre suspeita e diagnostico de casos de maus tratos e fraturas infantis, dado que, na literatura nacional, os estudos ainda são escassos sobre o tema. Métodos: Estudo retrospectivo envolvendo prontuário eletrônico de um hospital público de referência, em um município do estado de São Paulo, num período de 8 anos (2010 a 2018). Foram selecionados casos envolvendo crianças de até 12 anos notificados como maus tratos e apresentando fraturas, sendo os dados submetidos análise estatística. Resultados: Dentre 83 casos de maus tratos, um total de 19 pacientes (20.5\%) apresentaram 23 fraturas diferentes. As vítimas em 68,42\% eram meninos com média de 5 anos de idade que sofreram agressão física (79\%). A maioria não teve agressor identificado (52\%), sendo $21 \%$ relacionado a mãe. Os padrões de fratura encontrados envolveram em sua maioria fraturas de crânio (43,48\%) e fraturas diafisárias (34,78\%). Sete pacientes $(30,43 \%)$ tiveram outras lesões associadas e quatro pacientes vieram a óbito (21\%). Conclusão: Apesar do número de casos, foi possível identificar características e padrões relevantes. Tais dados apontam que o diagnóstico é subestimado e mostram pequenas diferenças epidemiológicas comparativas a literatura internacional. Nível de Evidência II, Estudo retrospectivo.

Descritores: Maus-Tratos Infantis. Agressão. Fraturas Ósseas. Criança.

Citation: Pereira VL, Crisostomo BL, Silva GC, Dobashi ET. Correlation between fractures and abuse in children: a retrospective analysis. Acta Ortop Bras [online]. 2021;29(1):30-3. Available from URL: http://www.scielo.br/aob.

\section{INTRODUCTION}

Child abuse refers to violence committed against children and adolescents in the family, institutional or social environment. ${ }^{1}$ One of the first descriptions of orthopedic manifestations directly related to child abuse was performed by Caffey $^{2}$ in 1946, describing metaphyseal lesion of long bones in children with multiple injuries, and later coining the term "corner fracture," which is the fracture through immature metaphyseal bone near the growth plate. ${ }^{3}$

In 1962, Kempe et al. ${ }^{4}$ introduced the designation "battered child syndrome," which brought medical attention to the problem of child abuse and led to the creation of compulsory notification laws. Originally, child abuse was defined as a physical injury inflicted on children by their caregivers. Since then the definition has expanded to include physical neglect, exposure to danger and emotional and sexual abuse..$^{2,3}$

Another important term is non-accidental trauma: action resulting from an act of omission, direct or indirect action that results in harm to the child or impairs his/her health and physical, mental or emotional development. ${ }^{5}$

In addition to being a public health problem, exposure to child abuse is associated with negative long-term consequences, including

All authors declare no potential conflict of interest related to this article.

The study was conducted at Universidade Federal de São Paulo, Paulista School of Medicine.

Correspondence: Bernardo Lopes Crisostomo. Rua Três de Maio, 82, apto 23, São Paulo, SP, Brazil. 04044020. bernardolopescrisostomo@gmail.com 
involvement with the criminal system ${ }^{6}$ and recurrent use of mental health services. ${ }^{7}$

The Brazilian Penal Code foresees, in Article 136, the crime of child abuse and since the implementation of the Child and Adolescent Statute, through the Federal Law No. 8069, health professionals are obliged to notify suspected or confirmed cases of abuse against children and adolescents. ${ }^{8}$

Zimmerman et al. ${ }^{9}$ reported that $50 \%$ of 243 abused children were under the age of one and $78 \%$ were under the age of three; $80 \%$ of the fractures were due to abuse in children under 18 months ${ }^{3}$ and abuse was the third cause of death of 1 to 4 -year-old children. ${ }^{5}$ Younger children have a higher death rate due to maltreatment. ${ }^{2}$ In children under the age of three, $20 \%$ of fractures caused by maltreatment are misdiagnosed or attributed to other causes. ${ }^{3}$ In addition, fractures may go unnoticed by poorly done or misinterpreted radiographs. ${ }^{10}$

The incidence of fractures in children ranges from $8-12 \%$ in the literature. ${ }^{11}$ Contusions are the most common injuries, followed by fractures; ${ }^{10,12}$ thus, orthopedists play an important role in the recognition and diagnosis of non-accidental trauma, ${ }^{3}$ participating in the initial evaluation of these patients. Maltreatment diagnosis can be difficult and requires high suspicion on the part of the professionals. ${ }^{5}$ This hypothesis can be ignored as a diagnostic possibility due to intentional change of story to mask abuse, causing misdiagnosis during the initial evaluation of the patient. ${ }^{13}$

When suspicion is raised, radiographic investigation should include anteroposterior incidences and profile of all bones of the appendicular skeleton, skull, chest and lumbar spine with separate cervical spine profile vision and anteroposterior incidences of the thorax, abdomen and pelvis, all in separate films. Oblique incidences of ribs are recommended and very useful. Each $x$-ray should be analyzed for signs of maltreatment, especially in the presence of specific abuse lesions, such as posteromedial fractures of ribs, corner and scapula fractures, sternum fractures and spinous processes. ${ }^{14} \mathrm{It}$ is important to note that although numerous studies have described fracture patterns that suggest abuse, there is no pathognomonic pattern and it is impossible to determine whether the child has been abused based soly on radiographies. ${ }^{5}$

To identify child abuse as a cause of fractures, doctors should consider factors such as change in story or inconsistency with the injury, delay in seeking treatment, age of the child, location and type of fracture, as well as the mechanism of trauma involved (fracture of long bones in children under one year old, multiple fractures in different stages of healing, corner fractures, rib and skull fractures) and presence of other injuries (burn injuries and unexplained soft tissue injuries). Even less specific injuries become highly suspicious when a good story is not provided. ${ }^{14}$ In view of these findings, the activation and notification of the authorities for the protection of children should be considered at the same time as other causes are investigated. ${ }^{2,10}$

Misdiagnosis, failure to identify the lesion and appropriate intervention increase the risk of progressive and repetitive abuse, with potential permanent consequences for the child and increased morbidity and mortality. ${ }^{2,5}$ The rate of new injury in beaten children is around 30 to $50 \%$, and the risk of death is between 5 and $10 \%$. $^{2,13}$ If a new injury occurs, it is likely that the caregiver will seek care in a different medical service and the risk of death increases with each new emergency service visited. ${ }^{2}$ At the same time, the embarrassment caused to an innocent family accused of abuse can cause conflicts in family dynamics. ${ }^{7}$

We believe that cases of fractures related to child abuse and maltreatment are underestimated by physicians and the injury patterns are poorly known. There are no established protocols to optimize the diagnosis and proper notification of suspected cases. Thus, we aim to identify the relationship between suspicion and diagnosis of cases of maltreatment and fractures in children, determining the risks and associated factors. We also intend to describe the epidemiological profile of abuse reports related to fractures. In our knowledge, there are no studies of this type involving the Brazilian population.

\section{MATERIALS AND METHODS}

Initially, the study was submitted to the Ethics and Research Committee of hospital São Paulo, Universidade Federal de São Paulo and approved under number $3,521,862$. This is a retrospective study involving the review of the care performed by the Orthopedics team of the General Hospital, from 2010 to 2018, and the Free and Informed Consent Form was not applied. Thanks to the work of collecting and organizing of the Hospital Epidemiological Surveillance Center, it was possible to catalog all treated injuries recorded during this period. We identified in electronic medical records of children (from birth to 12 years old) cases reported as maltreatment and abuse. Based on this data, we sought to identify relevant patterns. We cataloged the presence and characteristic of fractures and associated lesions in these diagnoses, as well as the type of aggression and epidemiological data involved.

\section{RESULTS}

The place where the study was conducted is a tertiary hospital in the state of São Paulo, which receives cases of greater complexity. In the 8-year analyzed period, 3106 diseases were identified, notified and registered by the Epidemiological Surveillance Center of the referred hospital. Among them, 83 cases (2.67\%) were identified as aggression and maltreatment in children from birth to 12 years of age. We found patients from six different cities. Out of the identified 83 cases, 54 involved physical aggression (65\%), 15 cases involved suicide attempts (18\%), eight cases were identified as negligence (9.6\%), four episodes involved sexual abuse (4.8\%) and two cases, abandonment (2.4\%). Among these categories, a total of 19 patients (20.5\%) presented 23 different fractures.

Among the patients who were victims of fractures, we found 13 boys (68.42\%) and six girls (32.58\%) with a mean age of five years old (range from 1 month to 12 years old). Only four did not suffer physical aggression (21\% versus $79 \%$ victims of aggression); three were cases of neglect (15.8\%) and there was one case of suicide attempt (5.25\%).

The forms of aggression predominantly involved direct body strength (seven cases, 36.84\%) and aggression with firearms (five cases, $26.31 \%$ ), two episodes (10.5\%) involving instruments (metal and wood bar), three episodes of fall (15.75\%), one suicide attempt, one push and one victim of negligence (5.25\% each). Two cases had no elucidated trauma mechanism (children were already abandoned presenting the lesions).

Ten cases had no identified aggressor (52\%), four were related to mother (21\%), three related to father (15.8\%), two to stepfathers (10.5\%), one to police officers and one to sister (5.25\% each). Two patients had more than one aggressor (mother and stepfather in both cases).

The fracture patterns found involved 10 skull fractures $(43.48 \%)$, eight diaphyseal fractures (34.78\% of which were in the humerus, two in the femur, two in the tibia and one in the forearm), a supracondylar humerus fracture, a palate fracture, a clavicle fracture, a rib fracture and a wrist fracture (adding up 21.74\%). Three patients had two or more fractures (15.8\%) and, of the total, two fractures were exposed (8.7\%). Seven patients (30.43\%) had associated lesions; the observed lesions were pulmonary contusion, pneumothorax, subdural/extradural bruises and cerebral edema. Four patients died (21\%). 
All cases were investigated by the Guardianship Council and public agencies. Two had their custody retained by the guardianship council during hospitalization (10.5\%), the others were characterized as maltreatment in a second moment.

\section{DISCUSSION}

Despite the choice of a large tertiary hospital - a reference in a populous region that receives patients from multiple municipalities in a period of extended temporal analysis and, consequently, covering a large number of patients involved in injuries, we had a relatively small number of cases. This finding is in favor of probable and important diagnostic mistakes and failure to detect cases of child abuse.

The incidence of child abuse is difficult to be determined, even though we find several data and studies discussing the relationship between fractures, maltreatment and their notification in the foreign literature. The Brazilian literature presents few information on the subject. In the United States, more than three million cases of child abuse or neglect are reported annually. ${ }^{15}$ Comparing with the Brazilian Institute of Geography and Statistics (IBGE) ${ }^{16}$ data and the incidences reported in international studies, the number of cases found in this study is much lower than expected.

It is interesting to note that the nineteen cases reported as suspected maltreatment were afterwards confirmed by public agencies. This suggests that notifications are likely biased, associated with fear of misdiagnosis, so that health professionals probably only reported cases explicitly indicative of abuse.

In an overview, we observed that the type of aggression suffered by most children was physical, followed by suicide attempts (abuse of multifactorial origin) and negligence. Predominantly, the aggressions involved direct body strength or the use of instruments, especially firearms; this may be related to the precarious socioeconomic condition and the social pressures imposed on the population of the cities involved in the study.

Most of the aggressors were not identified, however, mothers were the most identified aggressors, followed by fathers. The aggressions were higher in boys and the average age of the children was five years old. Such data are partly consistent with the literature.

Statistical analyses of internationally reported cases have shown that children are more susceptible to abuse by caregivers when younger and of worse social condition. Abuse is also less likely to be reported when it is emotional rather than physical and when the mother is the main agressor. However, maltreatment in families with higher purchasing power and social status may be underreported by health professionals, who wish to protect individuals of that social class of the stigma of investigation by public entities. ${ }^{2}$ We recall that the population of our study is predominantly poor, SUS users and residents of socioeconomically fragile areas.

Classically, long bone fractures in children under one year of age were considered highly suggestive of maltreatment, as children at this age would be unable to produce trauma with sufficient energy. ${ }^{17}$ However, it was later found that this was not true. Kleinman et al. classified the specificity of fractures due to maltreatment in three categories, according to their probability of being abuse-related. ${ }^{18}$ Fractures of high specificity are metaphyseal lesions (corner fracture), ribs in their posterior aspect, scapula, spinous processes and sternum. Those of moderate specificity are multiple (bilateral) fractures at different ages or period, slip fracture through the physis (type I Salter-Harris fracture), vertebral fractures or subluxations, digit fractures and complex skull fractures. Finally, those considered low specificity are clavicle fractures, long bone diasphysis fracture, and linear skull fractures. ${ }^{18}$

Most of the reported fractures involved the skull, mainly the parietal bone. The second most common type of fracture involved long bones. It is interesting to note that the fractures most associated in the literature with maltreatment were not found in this study (except for rib fracture, but we could not define its topographic position).

We believe that it is essential to remember that the diagnosis of maltreatment should never be made only by the study of radiographic patterns, ${ }^{5}$ and the findings described reinforce the need to expand clinical investigation on the etiology of lesions even in the presence of less associated types of fractures.

The mortality rate reported in foreign studies for children who were beaten was lower than in our study (5 to $10 \%^{2,5}$ versus $21 \%$ ). This finding may point out to the presence of a worse prognosis in relation to severity in children who presented fractures, or the higher notification of severe cases.

For ethical, technical and operational reasons, our data analysis came from cases reported as suspected maltreatment in the hospital. This certainly led to the loss of unreported suspected cases. Among the limitations of this study, we should mention the number of patients found in hospital records referred to as maltreatment, despite the long period investigated. This limits the statistical strength of association of the data. We should also remember the biases inherent to retrospective scientific studies, such as the bias of response selection, inaccuracy and lack of information. We remember, however, that this is a pioneer study: there are no other similar studies in the Brazilian literature involving fractures and child abuse. This is an important initial step to better understand the main characteristics of these complex cases in our reality, to optimize their detection and develop diagnostic, guidance and conduct protocols.

\section{CONCLUSION}

Among the 83 reported cases of maltreatment, a total of 19 patients (20.5\%) presented 23 different fractures. Despite the small number of cases, it was possible to identify relevant characteristics and patterns. The victims were mainly boys (68.42\%) with a mean age of 5 years old (ranging from 1 month to 12 years old), who suffered physical aggression (79\%). The majority had no identified aggressor (52\%) and $21 \%$ were related to the mother. The fracture patterns found involved, mostly, skull fractures (43.48\%) and diaphyseal fractures (34.78\%). Seven patients (30.43\%) had other associated lesions and four patients died (21\%). All cases were investigated by the Guardianship Council and public agencies and definitively characterized as maltreatment. These confirm the hypothesis that the diagnosis is underestimated by health professionals and show small epidemiological differences compared with the international literature. Further studies are needed to better characterize and confirm the patterns found.

AUTHORS' CONTRIBUTIONS: Each author contributed individually and significantly to the development of this article. VLP: study conception and design writing of the article; BLC: data analysis and interpretation and writing of the article; GCS: data analysis and interpretation and writing of the article; ETD: study conception and design, review of intellectual content and final approval. 


\section{REFERENCES}

1. Secretaria de Assistência à Saúde. Notificação de maus tratos contra crianças e adolescentes pelos profissionais de saúde. Normas e Manuais Técnicos. Série A - n. 167. Brasília: Ministério da Saúde; 2002.

2. Caffey J. Multiple fractures in the long bones of infants suffering from chronic subdural hematoma. Am J Roentgenol Radium Ther. 1946;56(2):163-73.

3. Norrell K, Hennrikus W. The Risk of Assuming Abuse in an Infant with an Isolated Metaphyseal Lesion. Bone Joint J. 2017;7(3):e69-e73.

4. Kempe $\mathrm{CH}$, Silverman FN, Steele BF, Droegemueller W, Silver HK: The battered-child syndrome. JAMA. 1962;181(1):17-24.

5. Ghanem MAH, Moustafa TA, Megahed HM, Salama N, Ghitani SS. A descriptive study of accidental skeletal injuries and non-accidental skeletal injuries of child maltreatment. J Forensic Leg Med. 2018;54:14-22.

6. Edalati $\mathrm{H}$, Nicholls TL. Childhood Maltreatment and the Risk for Criminal Justice Involvement and Victimization Among Homeless Individuals: A Systematic Review. Trauma Violence Abuse. 2017;20(10):1-16.

7. Read J, Harper D, Tucker I, Kennedy A. Do adult mental health services identify child abuse and neglect? A systematic review. Int J Ment Health Nurs. 2017;27(1):7-19.

8. Waksman RD, Hirschheimer MR, Pfeiffer L. Manual de atendimento às crianças e adolescentes vítimas de violência. $2 a$ ed. Brasília: Sociedade Brasileira de Pediatria; 2018.
9. Zimmerman S, Makoroff K, Care M, Thomas A, Shapiro R. Utility of follow-up skeletal surveys in suspected child physical abuse evaluations. Child Abuse Negl. 2005;29(10):1075-83.

10. Flaherty EG, Perez-Rossello JM, Levine MA, Hennrikus WL. Evaluating Children With Fractures for Child Physical Abuse. Pediatrics. 2014;133(2):e477-89.

11. Rennie RT, Court-Brown CM, Mok JYQ, Beattie TF. The epidemiology of fractures in children. Injury. 2007;38(8):913-22.

12. Loder RT, Feinberg JR. Orthopaedic injuries in children with nonaccidental trauma: demographics and incidence from the 2000 kids' inpatient database. J Pediatr Orthop. 2007;27(4):421-6.

13. Ravichandiran N, Schuh S, Bejuk M, Al-Harthy N, Shouldice M, Au H, et al. Delayed identification of pediatric abuse related fractures. Pediatrics. 2010;125(1):60-6.

14. Dwek JR. The radiographic approach to child abuse. Clin Orthop Relat Res. 2011;469(3):776-89.

15. Mudd SS, Findlay JS. The cutaneous manifestations and commom mimickers of physical child abuse. J Pediatr Health Care. 2004;18(3):123-9.

16. Instituto Brasileiro de Geografia e Estatística. Sinopse do Censo Demográfico 2010. [Internet]. 2010 [accessed on 2020 Feb 13]. Available from: https://censo2010.ibge.gov.br/sinopse/index. php?uf=35\&dados $=12$

17. Kocher MS, Kasser JR. Orthopaedic aspects of child abuse. J Am Acad Orthop Surg. 2000;8(1):10-20

18. Kleinman PK. Diagnostic imaging in infant abuse. AJR Am J Roentgenol. 1990;155(4):703-12 